\title{
CONTEMPORARY EXPRESSIONS OF PERSONAL LAW: CO-EXISTENCE OR CONFLICT WITH THE TERRITORIAL LAW?
}

\begin{abstract}
The paper concerns the present role played in law-in-the-books and law in action as well by a very traditional law type, namely that of personal law. In spite of the dominating role that the other type, i.e. territorial law, has played in Western law for more than a thousand years, there are numerous contemporary expressions of the existence and application of personal laws. In particular, this is the case of the vivacity of traditional personal laws characteristic of nonWestern legal traditions (above all shari'a), including attempts at their application in the Western environment. There are also various other examples of the recognition, at least in the practice, of personal laws in the Western law jurisdictions, which is indicated with the example of Polish law.
\end{abstract}

Keywords: personal laws, territorial law, shari'a, legal multivalence, conflict of laws.

\section{WSPÓLCZESNE PRZEJAWY ZASADY OSOBOWOŚCI PRAWA: WSPÓŁISTNIENIE CZY KONFLIKT Z ZASADĄ TERYTORIALNOŚCI PRAWA?}

Streszczenie. Opracowanie dotyczy obecnej roli, jaką w przepisach prawa i w praktyce jego stosowania odgrywa tradycyjna zasada osobowości prawa. Mimo dominacji, występującej od ponad tysiąclecia, zasady przeciwnej, tj. terytorialności prawa, napotkać można wiele współczesnych przejawów występowania i stosowania zasady osobowości prawa. Dotyczy to, w szczególności, żywotnych tradycyjnych praw osobowych charakterystycznych dla niezachodnich tradycji prawnych (w pierwszym rzędzie szariatu), w tym prób ich stosowania w otoczeniu zachodnich społeczeństw. Są także inne różne przykłady uznania, co najmniej w praktyce, przejawów osobowości prawa w państwach zachodnich, co jest wykazywane na przykładzie Polski.

Słowa kluczowe: osobowość prawa, terytorialność prawa, szariat, multicentryczność prawa, kolizja praw.

In accordance with the general scope of the author's scientific interests, that is to say law and legal science, the present paper concerns problems that can be qualified as the reverse of the subject of legal geographical inquiries (e.g. Dudek, Eckhardt and Wróbel 2018). The choice of the problem - the present role played in law-in-the-books and law in action by a very traditional law type, namely that of personal law - is not an effect of the author's perversity (though perversity

* SWPS University of Social Sciences and Humanities, Faculty of Law, Warsaw, Poland, hizdebski@swps.edu.pl 
with respect to what the others do is not the worst approach that can be adopted with regard to scientific activity), but it is rather a result of being inspired by the following passage from the study which reflected on the polemical paper from 2009 entitled "Can There be Maps of Law?" (Bavinck and Woodman 2009):

Reflections contained in the text [of both authors] concern mainly the territorial law. Personal law is a distinct category. Because of its specificity, expressing in the most general way in a link between legal norms and characteristic features of the given individual, and not the territory, (...) the contents and the scope of application of that law could not be fit to a cartographic take (Ptak-Chmiel 2018, 23).

The inspiration did not consist in simply following the author of these words in her reflection on the possibility of such application, but rather in seeing a need of a much broader treatment of the phenomenon referred to in the study as personal law.

It has to be noted that the term "personal law," can be confusing, and not only in Polish, because for a contemporary lawyer, in particular a European continental lawyer, personal law means mainly - if not only - a part or a branch of the private law in force on a given territorium iuris (or, according to the English terminology, a given jurisdiction); in Poland, the basic regulation thereof is to be found in Title II of the First Book of the Civil Code: "Persons." Therefore, in this meaning personal law cannot be an opposition to territorial law, i.e. law effective with respect to all the legal subjects acting in a given territory (in principle, the territory of the given state) or in a given jurisdiction, including the Polish civil law.

In the contemporary world dominated by the Western model of law, insofar as it is defined in opposition to territorial law, personal law constitutes a kind of exception to the principle of law territoriality. Therefore, from the historical point of view personal law can be perceived as a relic of non-Western legal traditions: in some jurisdictions formally recognized and, therefore, legally coexisting with the given territorial law; whereas in some other jurisdictions it is simply tolerated and therefore coexists de facto, while in other places it is rejected and therefore combatted, which does not automatically mean that a conflict between the two legal principles is always to be decided in favour of territoriality. One could ask what the causes of such different approaches are, and this paper attempts to provide a preliminary answer to that question. However, particularly in Polish law, there are expressions of personal law that are in no way relics of non-Western legal traditions. Noting them and searching for reasons why they are turned to is another aim of the present author.

Textbooks on the universal history of the state and law teach that the principle of personal law was in force for a prolonged period in ancient Rome, where ius civile, as the name suggests, was the law exclusively of Roman citizens in their legal relationships. Later, in the beginning of the Middle Ages, it was the law of 
the people belonging to a given ethnic group, that is, a tribe (e.g. Sczaniecki and Sójka-Zielińska 2016, 102-103, 137-138). In other words, only from the $10^{\text {th }}$ century did the principle of territorial law increasingly take shape at first in a relatively small spatial framework of relatively small jurisdictions (with the exception of England after the Norman conquest), and then, more and more, within the borders of emerging national states. It is necessary to point out that territorial law denotes a spatial separation of legal systems made on the basis of a political map, and not on any non-spatial criteria.

As far as national states are concerned, it has to be noted that relations of the state organization and the national substrate were shaped in different ways. In France, unlike many other European states, the state created the nation (which also explains the term l'état-nation) as well as the nation's law, and not vice versa. On the other hand, the creation of the state by the nation was particularly observable where the process of shaping the nation, identified for that reason on a different basis from the allegiance-citizenship of France, had preceded the establishment of the national state. The best examples thereof could be Italy and Germany, but also, though in different circumstances at the beginning and in the end of the national formation process, Poland - which was deprived of its statehood in the formative period of the nation.

Though the present paper is written in English, the following remarks may be important from the point of view of relationships between personal law and territorial law. The Polish word for the nation is naród. This word is composed of two elements. The first one, $n a$, is easy to translate and to explain in English, as it means simply "on," thus having a spatial, territorial connotation. The other element: ród can be directly translated into English as "kin" and/or "big family" (which also gives naród a personal flavour), but it is also noted that ród is closely associated with rodzenie, i.e. birth, which permits explaining naród as the space of na-rodzenie; on the other hand, however, narodzenie may be also associated with a large number of people (Tarasiewicz 2003, 5-8). Space in this context denotes a physical phenomenon, as well as a spiritual one, and the term na-rodzenie expresses, above all, the process of socialization in a given space, as well as the effects of such process.

The national state requires a certain intensification of the effects of $n a-$ rodzenie, but, independently from that, it bases itself on the force of public power, on imperium, and the law always plays the role (though not the exclusive one) of an instrument of power pertaining to a given territory. This is the national law, in the sense of the law of a given state (or a part of the state, constitutionally authorised and spatially allotted, in particular in a federal state) applicable to all who find themselves on its territory, which can serve as one of the most useful instruments for the exercise of imperium.

Traditional concerns focus on the national state and the national law. Until relatively recently, law - in the sense of a set of rules regulating behaviour of individuals and other legal subjects - was really confined within state borders, 
and international law, situated outside the national law, contained far more rules of international morality (as it was qualified almost 200 years ago by John Austin) than those of law. Today, however, the spatial dimension of law can largely extend beyond the space delimited by the state borders, which substantially changes the perspective on law territoriality.

The phenomenon, relatively well diagnosed, of the development of the multi-centric nature of contemporary law (Lętowska 2005) is accompanied by the phenomenon, not fully diagnosed, of the shaping of cosmopolitan and/or continental law, which is composed not only of "hard" rules but also of diverse elements of "soft" law. Nonetheless, cosmopolitan and/or continental law remains a territorial law, though having greater spatial coverage - or even much greater - than traditional national law.

The continued progress of territorial law, and the predominance of the principle of territorial law, is nowadays unquestionable. However, it is always possible to ask the question of whether the principle of personal law has really become merely a historical phenomenon totally superseded by the contemporary principle of territorial law.

In 1963, an English lawyer was able to state that:

(...) however the Personal Law may at some time been justified, that justification can no longer be supported today. (...) It emerged that the actual doctrine of the Personal Law was unsound in theory and unworkable in practice. (...) The time is ripe (...) for the Personal Law to be shown the gate to the field of legal history. There should be no difficulty in closing the gate behind it (Raeburn 1963, 125-126, 147).

More than half a century ago it was thus possible to arrive at an affirmative answer to the above question. The answer was supported by a kind of juristic occidentalism, that is, treating Western law with its principle of territorial law as the only appropriate - or at least workable - model of law in the contemporary world. Although occidentalism could be justified in the colonial era (in spite of the imperial authorities maintaining, in various forms, the personal law of the native population), it had less and less grounds in the period of decolonization and with the emergence of more and more postcolonial states that had no bases for a sense of national identity, in particular those typical of Southern and Central Europe. For many postcolonial states, territorial law was not the only type of law to be enforced, as their citizens had been accustomed to another type of law, i.e. personal law. In Africa, the idea of the territorial or spatial separation of legal systems could only be superimposed upon working and workable traditional legal systems (Allot 1970, 107).

One of the important proofs of occidentalism weakening was the development of the macro-comparison approach in the science of comparative law, besides 
the traditional interest in micro- and meso-comparison (Siems 2018, 13). In 1964 - a year after the publication of the above quoted condemnation of personal law - a very important book was published: "Les grands systèmes de droit contemporains" by René David, in which the phenomenon of the particular vitality of personal law had to be mentioned and explained within the presentation of nonWestern legal families; the book was soon translated into several major languages and became perhaps the most widely known comparative law book of its time (Fauvarque-Cosson 2006, 46), and is still published, obviously in an updated form (David, Jauffret-Spinosi and Goré 2016).

Today, it would be difficult to write a book on macro-comparative law without taking into account the existence of personal laws, or even without such concluding observations:

There are conflicting principles, and much of the theoretical debate is in terms of these conflicting principles. On the one hand there is a notion of citizenship which would demand exclusive loyalty to the state and which would relegate other legal traditions, if recognized at all, to the realm of a purely private sphere. On the other hand there is the model of "personal laws", representing the co-existence of different legal traditions and groups, which would (perhaps fatally) weaken the structure of the state. In the law of the states of the world, solutions are usually found between these two poles (...) Multivalence in law is in the order of the day, whether recognized in political or state theory or not-

followed by treating jurisdictions which recognize personal laws as something natural and susceptible of persistence (Glenn 2007, 364-365).

The present interest of legal comparatists in the phenomenon of personal law arises, on the one hand, from the continuing formal situation. Personal laws are recognized, and to a large extent by the legislation, as the source of law in force - in the Republic of India, in Arab states, or in Israel (for a comparison of the situation in India and Israel, see Subramanian 2014). Such recognition means, however, a certain territorialization of personal law - applied to persons who want to be subject to it, but according to the substance and procedures admitted within borders of the particular state, and by its courts of law.

On the other hand, one has to notice diverse practical phenomena outside the legislative regulation of particular states, and sometimes formally contrary to regulation. In particular, there is no legislative basis for an application by courts of law in the Republic of South Africa, in a limited field, of the "non-state law" of inhabitants - citizens ("non-state law" is nothing else than personal law), instead of the "state law," i.e. the territorial law (Rautenbach 2014). There are also attempts at solving, even in contravention of the legislation of the place, problems resulting from migrations of persons who, being attached to the tradition of the choice of law typical of the model of personal law, want to preserve their personal law while 
living in countries ruled by Western law. The latter problems concern above all shari'a, the very vital personal law of Islamic people, though not only (in Poland, there was a well-known example, subject to judicial examination, of a Sikh who did not want to remove his turban in the course of the border control, and the turban had been taken off by force). Generally speaking, personal laws, except for the customary laws of some African peoples, are inseparably linked with a given religion, and they are based upon the lack of distinction between the orders of the law and orders of the religion.

In those states which develop their territorial law but which also formally recognize personal laws as well, the application of personal law is, in principle, limited to "personal status." While using our classification of branches of the law, this "status" can amount to personal law, family law, and the law of succession. Moreover, it is not at all accidental that the field of "personal status" is very close to the scope of the historical application of the Canon Law to laics (this law is also a kind of personal law based upon religion but differing from Talmudic, Islamic or Hindu law).

In the Republic of India, where the most developed juristic reflections on the effects of the model of personal laws (limited to the field of "personal status") are to be found, there are, formally recognized by the series of legislative acts dating back mainly to the time of the British rule, personal laws of: the Hindu people, the Muslim people (in the 1937 Muslim Personal Law Application Act explicitly named Shariat) and Christians. Particular legislative acts relate to the marriage law of Zoroastrian Persians (Parsi), and the marriage law of Jews is respected without respective legislation. However, the experts mention that the legal value of those laws originated rather in the decisions of the British colonial authorities than in the force of the religions standing behind each particular law - "there is nothing inherently personal about personal laws" (Agarwalla 2018 - and to compare, Mouloi 1880), but respective decisions did not simply result from the discretion of the British but were an effect of pressures from elites of particular communities, leading even to alterations of their legal systems in ways that served their own interests (Newbegin 2009). Whereas followers of Hinduism agree with increasingly stronger regulation of their status by means of legislative acts that implement the constitutional principle of the equality of women and men, Muslims defend their legal autonomy. This means that in India there is a sufficiently strong socio-political basis for maintaining the formal coexistence of the core of both personal law and territorial law. Art. 44 of the Constitution of the Republic, declaring that "the State shall endeavour to secure for the citizens a uniform civil code throughout the territory of India" remains a vague programmatic address, and is not an expression of a legal norm.

In any case, the example of India has proved that the 1963 statement on the purely historical nature of the model of personal law was at least premature, and, 
taking into account the richness of the Indian legal doctrine relating to that subject (and thus not only Hindu), the author's thesis that "the actual doctrine of the Personal Law was unsound in theory and unworkable in practice" was completely inadequate, as it is inadequate today.

Legal comparatists, having a vested interest in the experience of India, tend not to note another example of a formal declaration of the principle of personal law coexisting with that of territorial law. The 1960 Constitution of the Republic of Cyprus, a country inhabited by the members of two communities - Greek and Turkish - divided the legislative power among the national House of Representatives and two Communal Chambers representing Greek and Turkish Cypriots, respectively. The Chambers are to dispose legislative powers not only with regard to, for instance, all educational, cultural, and teaching matters (which could suggest a federal form of government, though without a respective territorial division of the Republic) but also - or rather above all - with regard to all religious matters, personal status, and the composition and instances of courts dealing with civil disputes relating to personal status and to religious matters. The sphere of personal status, together with that of religious matters, is thus constitutionally legitimated in the state, which is member of the European Union. It is another matter that the Cypriot constitution has not worked in this respect since 1963 because of the dispute between the Greek and Turkish Cypriots and, then, between Turkey and Greece, including Turkey's military intervention; the territory of the Republic is de facto divided into the self-proclaimed Turkish Republic of Northern Cyprus and the territory fully administered by Greek Cypriots. The lack of application could also be a reason for legal comparatists lacking interest in those particular solutions aimed at protecting the rights, including personal status, of Turkish Cypriots.

The conflict between personal laws in general (legal disputes between persons representing different personal laws) and in particular (examined in the context of the territorial law - still more difficult to solve when the dispute proceeds on another territorium iuris, which occurs quite frequently in marriage law) belongs, together with the formula of choice of law, to the field of private international law.

It is very characteristic that the contemporary doctrine represented by those few who are interested in the conflict of personal laws does not differ substantially from what was elaborated in that field in England a century ago (Robertson 1918), which inclines one to agree only partially with the somewhat different opinion - expressed in 1976 - of a representative of Islamic legal doctrine and an expert in private international law (Tier 1976). Nonetheless, it cannot be disputed that the issue was largely ignored by the mainstream scholars of private international law, despite the fact that the conflict of laws has been a crucial issue for this branch 
of legal science. The silence was a result of the conviction that the problem was only of historical importance, and there were also some authors who added an another argument: typical schemes of private international law, such as lex fori, lex situs, lex loci contractus, or lex domicile, are incompatible with the conflict of personal laws, because those laws overlap on the same territory, and the legislation of a given state relating to the judiciary organization decides whether there are distinct courts of law for particular personal laws or the same court of law could be competent for different personal laws - and the latter solution complicates the life of diverse legal communities, which makes those in a given jurisdiction search for sophisticated rules (Tier 1986).

On the other hand, one could speak about a distinct - to a certain extent - doctrine of conflicts pertaining to formally recognized personal laws. The undeniable vitality of Islamic law is an important factor in the need for the development of such doctrine, which has to be, by definition, sophisticated.

The theme of contemporary expressions of personal law, however, is not exhausted by evoking relationships between formally recognized non-Western personal laws with a religious basis and the territorial law of the state recognizing those laws, since it would be difficult not to notice various other expressions, and, moreover, within the framework of Western law, which is territorial in its essence. The other thing is that the expressions found within Western law are dispersed and seem to be less important than those examined above, despite the fact that, since they arise out of the political and/or social need to have them within the legal system, it is difficult to call them simple or unsophisticated.

To start from the sphere of the "hard" law, one such expression is the typically personal (and also typical for Western law) application of the Polish penal legislative act to Polish citizens who committed a criminal offence abroad (the principle stipulated in Art. 109 of the Criminal Code), unless (Art. 111) it is not considered an offence by the law in force where it was committed (except, however, for a Polish public official who has committed an offence while performing his duties or a person committing an offence in a place not under the jurisdiction of any state authority). Art. 109 and Art. 111 of the Polish Criminal Code can be treated as an exception from the principle of territoriality - declared in Art. 5 of the Code:

Polish criminal law applies to an offender who commits a prohibited act in the Republic of Poland, or on a Polish vessel or aircraft, unless the Republic of Poland is party of an international agreement stating otherwise.

As other exceptions, one could indicate the various particular privileges, provided for in international agreements or in constitutional and statutory provisions, 
of a given group of persons. They concern, in particular, immunities: diplomatic and consular above all, but also substantive and formal parliamentary immunity.

A very special privilege resulted from the interpretation, presented in the 1991 judgment of the Polish Supreme Court, of the provision of the Criminal Code pertaining to passive bribery, i.e., accepting bribes (at present, it is Art. 228 of the Code), leading to the exclusion of responsibility of persons performing public functions in a foreign state or in an international organization. However, the exclusion disappeared as a result of the ratification by the Republic of Poland of the Paris Convention on Combatting Bribery of Foreign Public Officials in International Business Transactions - not by a change of interpretation but by adding an explicit provision to the Criminal Code (Izdebski 2011, 282). Moreover, the Convention is an example of the development of "cosmopolitan law," which is still territorial, but on a scale much larger than any national law. The best example of "cosmopolitan law" is the Rome Statute of the International Criminal Court (Benhabib 2007).

It is also justified to qualify the right of Polish nupturients to choose so-called concordat marriage, ruled by Canon Law, and taking simultaneous effect in the field of state law, as a specific expression of the formal application of personal law. This form of marriage was reintroduced by the Polish government, following the Concordat concluded in 1993 with the Holy See, thereby taking advantage of the great devotion of the Polish people shown to the Catholic religion, and aiming at having the best relations with the Catholic Church.

At the border between the law (partially "soft") and simple practice, we can identify another expression of the working of personal law in Poland. This is the recognition, within constitutionally guaranteed autonomy of churches and other religious communities, of the special legal status of clergymen which, with respect to clergymen of the Catholic Church, can lead (and, moreover, has led) to their - practical, if not formal - exemption from the operation of the territorial law; in particular as far as sexual offences are concerned, with priority - if not monopoly - being too frequently attributed to the respective provisions of the Code of Canon Law.

As far as the practical phenomena relating to expressions of personal law are concerned, the most important are those which are connected with migrations of persons who want to retain, in the states under Western law, their own law, also observing a personal law tradition of the choice of law. This concerns, above all, followers of Islam, and therefore of shari'a.

Formally, in Western states there is no room for shari'a-except for certain of its elements (such as validity of marriage) - in situations where, even though it has been recognized within the field of personal status in the Republic of India or in numerous Arab states, the rules of shari'a are in a conflict with the relevant 
territorial law. In that field, solutions should and could be provided by the rules of private international law.

However, conservative or radical Islamists try to go beyond that limited range of shari'a's operation, and, going beyond operating in an "underground system" (Black 2010, 65), and try to bring about its practical operation to a much larger extent. Thus, there can be attempts to apply shari' $a$ as a basis for adjudication in formalized and recognized institutions of alternative dispute resolution (ADR). There are experiences of debates in the Canadian province of Ontario in 20032006 which led to a certain formalization of Islamic arbitration in family law (Boyd 2007; Korteweg and Selby 2012), and then of similar debates in Australia, without, however, leading to a similar effect (Black 2010). On the other hand, in the German Islamic Charter, the official document of Muslims of Germany, there is the following provision: "The command of Islamic law to observe the local legal order includes the acceptance of the German statutes governing marriage and inheritance, and civil as well as criminal procedure" (Black 2010, 67). Legal multivalence may, therefore, have different faces due to the historical experiences and socio-cultural background of particular Western countries.

Conservative or radical Islamists can also try to benefit from, or abuse, the freedom of religion - one of the generally recognized fundamental rights. That freedom is not generally considered to be absolute - in spite of what was stated orally by the President of the Polish Constitutional Tribunal while justifying the judgment of the Tribunal of the $10^{\text {th }}$ of December 2014 relating to the ritual slaughter - and neither is it almost absolute, as was stated in the written justification of the judgment. However, the extent to which it may be limited while protecting other constitutional and international principles and values (there is reference to Art. 9 of the European Convention on Human Rights and Fundamental Freedoms) is a matter of discussion (Olszówka 2016, 1273-1275), and the problem can be solved in different ways in different states. As an example of diverse approaches one can recall the legislation of some European states prohibiting women from wearing traditional Islamic burqas in all public places (such as in France, Belgium, Denmark or Bulgaria) or in some public places (the Netherlands); moreover, this prohibition was accepted in 2017 by the European Court of Human Rights.

In that field, however, it is not easy - and perhaps it is impossible - to make a distinction between matters of law and matters of politics, in particular the acceptance (or not) and comprehension of the policy of internal multiculturalism as a particular form of the protection of minority rights. As has been noted by a legal comparatist,

states such as the United States of America and France have (traditionally) placed greatest emphasis on exclusivity of citizenship and loyalty to the state. (...) In France the principle of secularity has been found by courts to be compatible both with the wearing of religious garb in schools (providing public order - a fuzzy standard - is not violated) and judicial orders designed to compel the granting of Talmudic divorces (Glenn 2007, 364-365). 
Jacob Soll, professor of philosophy, history and accounting (this combination is very original) of the University of Southern California has noted very recently (The New York Times, 2018):

Sophistication used to be valued, both as a way of looking at the world and a means of living in it. Now, as our affairs become dizzyingly complex and depressingly straightforward, it is getting lost. It's odd and it's troubling. We are losing our grasp of the general concept that things are complicated, and that deep knowledge - civic, political, cultural - is a perfect old tool for the challenges of the new world.

To be workable, the model of personal laws (or even elements of it in contemporary law) has to be sophisticated. It cannot be denied that they work practically all over the world - sometimes better, sometimes worse, in formal and/ or de facto coexistence with territorial law, or in conflict with it.

The existence of personal laws and their sophistication has had to be noted in contemporary comparative legal science; and also examined, taking into account the diversity of causes of different approaches in different countries, represented both by those who are partisans of the conservation of the principle of personal law and those who are attached to the principle of territorial law. The examination seems to be increasingly important, in particular to evaluate from their point of view the extent to which legal systems, including those entirely belonging to the Western law, are multi-centric and, protecting minority rights, multivalent as well.

\section{BIBLIOGRAPHY}

Agarwalla, Shubhangi. 2018. "A Transformative Approach to Personal Laws." IntLawGrrls. Accessed February 12, 2020. https://ilg2.org/2018/10/03/a-transformative-approach-topersonal-laws

Allot, Antony N. 1970. New Essays in African Law. London: Butterworths.

Bavinck, Maarten and Gordon Woodman. 2009. "Can There Be Maps of Law?" In Spatializing Law. An Anthropological Geography of Law in Society. 195-218. Edited by Franz von BendaBeckmann, Keebet von Benda-Beckmann and Anne Griffiths. Farnham: Ashgate.

Benhabib, Seyla. 2007. "On the Philosophical Foundation of Cosmopolitan Norms." In Law and Legal Cultures in the 21st Century: 23rd IVR World Congress, August 1-6, 2007. 66-68. Edited by Tomasz Gizbert-Studnicki and Jerzy Stelmach. Warszawa: Wolters Kluwer.

Black, Ann. 2010. "Legal Recognition of Sharia Law: Is This the Right Direction for Australian Family Matters?" Family Matters 84: 64-67.

Boyd, Marion. 2007. "Religion-Based Alternative Dispute Resolution: A Challenge to Multiculturalism." In Belonging? Diversity, Recognition and Shared Citizenship in Canada. 465-474. Edited by Keith Banting, Thomas J. Courchenne and Leslie F. Seidle. Montreal: Institute for Research on Public Policy.

David, René, Camille Jauffret-Spinosi and Marie Goré. 2016. Les grands systèmes de droit contemporains. Paris: Dalloz-Sirey. 
Dudek, Michał, Piotr Eckhardt and Marcin Wróbel, Eds. 2018. Przestrzenny wymiar prawa [Spatial Dimension of Law]. Kraków: NOMOS.

Fauvarque-Cosson, Bénédicte. 2006. "Comparative Law in France." In The Oxford Handbook of Comparative Law. 35-68. Edited by Mathias Reimann and Reinhard Zimmermann. Oxford: Oxford University Press.

Glenn, H. Patrick. 2007. Legal Traditions of the World. Oxford: Oxford University Press.

Izdebski, Hubert. 2011. Elementy teorii i filozofii prawa [Elements of Theory and Philosophy of Law]. Warszawa: LexisNexis.

Korteweg, Anna C. and Jennifer A. Selby, Eds. 2012. Debating Sharia: Islam, Gender, Politics, and Family Law Arbitration. Toronto, Buffalo and London: University of Toronto Press.

Łętowska, Ewa. 2005. "Multicentryczność współczesnego systemu prawa i jej konsekwencje" ["Multicentric Nature of the Contemporary System of Law and Its Consequences"]. Państwo i Prawo 4: 3-10.

Mouloi, Syed Ameer Ali. 1880. The Personal Law of the Mohammadians, According to All the Schools. Together with a Comparative Sketch of the Law of Inheritance Among the Sunis and the Shiahs. Reprint, 2018. London: Forgotten Books.

Newbegin, Eleanor. 2009. "The Codification of Personal Law and Secular Citizenship: Revisiting the History of Law Reform in Late Colonial India." The Indian Economic \& Social History Review 46(1): 83-104.

The New York Times. 2018. "The Big Question: Have We Left Something Important Behind?" December 7, 2018.

Olszówka, Marcin. 2016. [“Commentary to Article 53”]. In Konstytucja RP. Komentarz, tom 1: Art. 1-86 [Constitution of the Republic of Poland. Commentary, vol. 1: Art. 1-86]. 1247-1278. Edited by Marek Safjan and Leszek Bosek. Warszawa: C.H. Beck.

Ptak-Chmiel, Joanna. 2018. "Mapy prawa. Refleksje na kanwie polemiki Maartena Bavincka i Gordona Woodmana" ["The Maps of Law. Reflections Based on Maarten Bavinck's and Gordon Woodman's Polemic"]. In Przestrzenny wymiar prawa [Spatial Dimension of Law]. 11-31. Edited by Michał Dudek, Piotr Eckhardt and Marcin Wróbel. Kraków: NOMOS.

Raeburn, Walter. 1963. "Dispensing with the Personal Law." The International and Comparative Law Quarterly 12(1): 125-147.

Rautenbach, Christa. 2006. "Phenomenon of Personal Laws in India: Some Lessons for South Africa." The Comparative and International Law Journal of Southern Africa 32(2): 241-264.

Robertson, Frederick. 1918. "The Relations Between the English Law and the Personal Law of Indians in England with Special Reference to the Marriage Law." Journal of Comparative Legislation and International Law 18(2): 242-259.

Sczaniecki, Michał and Katarzyna Sójka-Zielińska. 2016. Powszechna historia państwa i prawa [Universal History of State and Law]. Warszawa: Wolters Kluwer.

Siems, Matthias. 2018. Comparative Law. Cambridge: Cambridge University Press.

Subramanian, Narendra. 2014. Nation and Family: Personal Law, Cultural Pluralism, and Gendered Citizenship in India. Stanford, CA: Stanford University Press.

Tarasiewicz, Paweł. 2003. Spór o naród [Debate on the Nation]. Lublin: Towarzystwo Naukowe KUL.

Tier, Akolda M. 1976. "The Relationship Between Conflict of Personal Laws and Private International Law." Journal of the Indian Law Institute 18(2): 241-278.

Tier, Akolda M. 1986. "Techniques of Choice of Law in Conflict of Personal Laws." Journal of African Law 30(1): 1-19. 